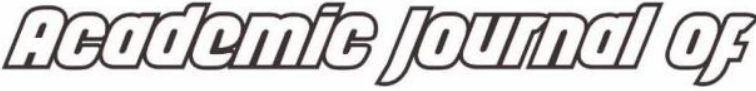

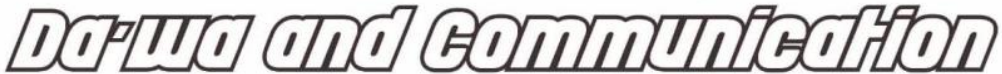

\section{MEDIA RELATIONS DINAS KOMUNIKASI DAN INFORMATIKA (DISKOMINFO) KABUPATEN KARANGANYAR DALAM SOSIALISASI PROGRAM PEMERINTAH}

\author{
Nur Laili Puspa Rohmana \\ Rhesa Zuhriya Briyan Pratiwi \\ IAIN Surakarta
}

\begin{tabular}{l}
\hline Keywords: \\
Media Relations; \\
Socialization; \\
Strategy \\
\hline
\end{tabular}

Alamat Korespondensi : lailipuspa36@gmail.com rhesa.pratiwi@gmail.com

Abstract
The importance of media relations conducted by a number of PRs in
Government Agencies has implications for government policies in
accordance with the information needs of the community. One of
them is at the Office of Communication and Information
(Diskominfo) Karanganyar Regency related to the issue of
government program socialization. This study aims to describe the
media relations strategy used by the Karanganyar Regency Office of
Communication and Information in the socialization of government
programs. The type of research used is descriptive qualitative. Data
collection techniques using observation, interviews, and
documentation. The results of the study, Diskominfo Karanganyar
Regency uses media relations strategies by managing relations,
developing strategies, and developing networks with the media to
optimize each role of each section in Diskominfo for the benefit of the
socialization of government programs for the community.


Kata kunci: Media Relations; Sosialisasi; Strategi

\begin{abstract}
Abstrak
Pentingnya media relations yang dilakukan sejumlah Humas di Instansi Pemerintahan berimplikasi pada kebijakan pemerintah sesuai dengan kebutuhan informasi masyarakat. Salah satunya adalah pada Dinas Komunikasi dan Informatika (Diskominfo) Kabupaten Karanganyar terkait permasalahan sosialisasi program Pemerintah. Penelitian ini bertujuan untuk mendeskripsikan strategi media relations yang digunakan oleh Dinas Komunikasi dan Informatika Kabupaten Karanganyar dalam sosialisasi program pemerintah. Jenis penelitian yang digunakan adalah kualitatif deskriptif. Teknik pengumpulan data menggunakan observasi, wawancara, dan dokumentasi. Hasil penelitian, Diskominfo Kabupaten Karanganyar menggunakan strategi media relations dengan mengelola relasi, mengembangkan strategi, dan mengembangkan jaringan bersama media guna mengoptimalkan masing-masing peran setiap bagian pada Diskominfo untuk kepentingan sosialisasi program pemerintah bagi masyarakat.
\end{abstract}

\section{PENDAHULUAN}

Penyebaran informasi publik pada dasarnya perlu melibatkan pemanfaatan berbagai sarana dan media komunikasi pemerintah sehingga dalam praktiknya, masyarakat sebagai publik yang menerima informasi selanjutnya dapat menerima, mengetahui, memahami, sekaligus mendukung program yang berkenaan dengan kebijakan pemerintah. Dalam hal ini, Dinas Komunikasi dan Informatika (Diskominfo) Kabupaten Karanganyar bertanggung jawab dalam pengumpulan dan pengolahan data informasi mengenai kegiatan Kabupaten Karanganyar, untuk kemudian dapat disebarkan kepada masyarakat sebagai bagian dari informasi publik.

Adapun informasi yang disampaikan kepada masyarakat oleh Diskominfo Kabupaten Karanganyar meliputi sejumlah data hasil liputan, baik berupa foto, rilis berita, maupun video yang telah diolah sebelumnya. Dalam melaksanakan tugasnya, Diskominfo Kabupaten Karanganyar bekerja sama dengan sejumlah media massa agar penyampaian informasi dapat berjalan secara lebih efektif. Konteks ini menunjukkan adanya publikasi sebagai bagian dari informasi yang tidak dapat dikontrol secara sepihak oleh organisasi saja, melainkan secara wajib harus melalui gate keepers, seperti jurnalis, reporter, editor, program direktor, yang bertugas untuk menyeleksi informasi (Wardhani, 2008). 
Pentingnya bahwa program pemerintah harus disampaikan kepada masyarakat, dalam hal ini Diskominfo Kabupaten Karanganyar dipandang sebagai salah satu perpanjangan Pemerintah Kabupaten Karanganyar yang memiliki tugas dan fungsi untuk melayani masyarakat Kabupaten Karanganyar dalam hal penyebaran informasi. Selain itu, Diskominfo Kabupaten Karanganyar harus mampu menjadi penghubung antara masyarakat dan pemerintah dalam rangka mewujudkan sosialisasi program atas sejumlah kebijakan Pemerintah Kabupaten Karanganyar.

Guna menunjang peran dan fungsi Diskominfo Kabupaten Karanganyar, diperlukan secara eksplisit mengenai kerjasama antara Diskominfo Kabupaten Karanganyar dengan beberapa media massa sekitar. Keberadaan media dalam hal ini berperan sebagai upaya penyebaran informasi dalam membantu humas Diskominfo untuk mengawasi perputaran informasi yang ada. Secara keseluruhan, adanya cakupan strategi dari Diskominfo Kabupaten Karanganyar merujuk pada perputaran informasi mengarah pada tiga persoalan utama ruang publik yang harus dikelola, yakni: hak publik yang harus dipenuhi, aspirasi masyarakat yang harus dikelola, serta kepentingan citra positif lembaga pemerintah yang harus dipenuhi.

Merujuk pada kepentingan untuk menyalurkan informasi kepada masyarakat, konsep selanjutnya yang dapat menjadi acuan adalah terkait keberadaan humas pemerintah. Terkait hal ini, humas pemerintah pada dasarnya diklasifikasikan oleh Sam Black menjadi dua, yaitu: humas pemerintah pusat dan humas pemerintah daerah (Effendy, 1986). Terkhusus pada humas pemerintahan daerah, tugas humas ini terfokus pada departemen yang secara inti memiliki dua tugas pertama, yakni: menyebarkan informasi secara teratur mengenai kebijakan, perencanaan, maupun hasil yang telah dicapai oleh instansi, serta menerangkan dan mendidik publik mengenai perundangan, peraturan, dan hal-hal yang bersangkutan dengan kehidupan masyarakat sehari-hari. Di samping itu, tugas seorang humas pemerintah daerah juga mengacu pada posisi sebagai penasihat komunikasi bagi pimpinan departemen dalam hubungannya dengan tanggapan publik terhadap kebijakan yang dijalankan.

Tulung (2014) menjelaskan bahwa penyelenggaraan pemerintahan Negara harus melalui praktisi Diskominfo, dimana organisasi harus mampu mengelola informasi publik yang ditujukan untuk kepentingan publik. Manajemen informasi publik yang dilakukan diupayakan menjadi sistem yang dapat diandalkan seluruh lembaga pemerintah guna berkomunikasi dengan publiknya. Dalam konteks ini, manajemen 
informasi publik adalah proses dan prosedur yang dilakukan lembaga pemerintah dalam menyebarkan informasi yang ingin, perlu, dan harus diketahui oleh publik.

Merujuk pada uraian di atas, Diskominfo Kabupaten Karanganyar dalam praktiknya memanfaatkan media dalam menyampaikan informasi kepada masyarakat dan berkomunikasi di ruang publik. Sebut saja, media cetak, media penyiaran, media tatap muka, media luar ruang, media tradisional (pertunjukan rakyat), serta media online (internet). Terutama dalam penggunaan fasilitas media online salah satunya, Lmelalui pengelolaan Diskominfo Kabupaten Karanganyar, Pemerintah Kabupaten Karanganyar memiliki Website resmi yang dapat diakses pada laman www.karanganyarkab.go.id; akun Facebook Kabupaten Karanganyar; Twitter @karanganyarkab; Instagram di alamat @kabupatenkaranganyar; serta Youtube dengan nama Kabupaten Karanganyar. Lebih lanjut, tercatat pengunjung Website www.karanganyarkab.go.id yang dibuat sejak awal berdasarkan survei www.similarweb.com hingga 27 November 2018, pengunjung Website tersebut berkisar sebanyak 252.006,000 pengunjung, Fanspage 7.779 penyuka, Twitter sebanyak 2.542 pengikut, Instagram sebanyak 17.004,000 pengikut, dan Youtube dengan 1.242 subscriber dan 179 video yang diunggah.

Peran, fungsi, dan keberadaan pemerintah daerah, dalam posisinya diatur dalam Undang-undang Republik Indonesia Nomor 32 Tahun 2004 tentang Pemerintah Daerah (RI, 2004), yaitu bahwa yang dimaksud dengan pemerintahan daerah adalah penyelenggaraan urusan-urusan pemerintah daerah dan DPRD menurut asas otonomi dan tugas pembantuan, dengan prinsip otonomi seluas-luasnya dalam sistem dan prinsip NKRI. Pemerintahan dalam konteks ini juga dapat dijabarkan sebagai organisasi yang memiliki kekuasaan untuk membuat dan menerapkan hukum serta undang-undang di wilayah tertentu.

Adapun Pemerintah Kabupaten Karanganyar dalam menjalankan urusan Negara dalam hal kebijakan pemerintahan, salah satunya adalah berkenaan dengan pelayanan masyarakat. Hal ini memerlukan komunikasi yang baik kepada masyarakat demi tercapainya tujuan bersama. Di sinilah peran Diskominfo daerah sebagai pusat komunikasi harus dapat dioptimalkan untuk kepentingan publik. Peran Diskominfo adalah menjelaskan program dan kebijakan pemerintah terhadap warganya. Instansi ini menyampaikan urusan dan rencana resmi pemerintah pada masyarakat sehingga 
mereka bisa memahami bagaimana program dan kebijakan yang disusun oleh pemerintah selanjutnya dapat dimanfaatkan secara optimal oleh masyarakat.

Penyebaran informasi oleh Diskominfo tentu harus menjangkau khalayak tepat sasaran sebagai bentuk edukasi publik. Dalam hal ini, fokus strategis edukasi publik memperlihatkan kepada kita betapa beragamnya kondisi masyarakat pengakses informasi. Di wilayah Karanganyar misalnya, terdapat sejumlah sasaran khalayak edukasi publik yang masih berada pada situasi dan kondisi yang belum terakses informasi. Terdapat juga konteks masyarakat yang sudah terakses informasi, tetapi belum bisa optimal dalam pemanfaatannya, terlepas ada pula sebagian masyarakat yang terakses informasi dan telah mampu memanfaatkan informasi tersebut dengan baik. Dengan kata lain, persebaran informasi di seluruh lapisan masyarakat di wilayah Karanganyar dinyatakan belum merata.

Konteks penyebaran dan pemerataan informasi publik ke seluruh lapisan masyarakat dibutuhkan aktivitas pelancaran arus informasi publik. Salah satu elemen bagi terciptanya pelancaran arus informasi publik adalah penetapan agenda setting, terciptanya jaringan komunikasi, koordinasi antar lembaga-lembaga pemerintahan di pusat dan daerah dalam penyediaan dan pelayanan informasi publik, serta terciptanya program komunikasi yang terkoordinasi dan berkelanjutan antara lembaga publik dengan masyarakat.

Menilik pada permasalahan di atas, diperlukan adanya kerjasama dan relasi dengan media oleh setiap lembaga pemerintahan, tak terkecuali Diskominfo Kabupaten Karanganyar, dalam menunjang program kebijakan Pemerintah Karanganyar. Relasi media diperlukan untuk mengontrol berita yang dimunculkan oleh media, sekaligus sebagai media branding bagi lembaga bersangkutan. Diskominfo Kabupaten Karanganyar tentu menyadari bahwa posisi media sangat penting dalam membantu program dan kegiatan humas. Hal ini sejalan dengan pemikiran Jefkins (1995) yang menyatakan tentang hubungan pers (press relations) sebagai usaha untuk mencapai publikasi atau penyiaran yang maksimum atas suatu pesan atau informasi humas. Tujuannya adalah untuk menciptakan pengetahuan dan pemahaman bagi khalayak dari organisasi atau perusahaan yang bersangkutan.

Wujud kerjasama Diskominfo Kabupaten Karanganyar dengan beberapa media, beberapa di antaranya dapat ditunjukkan dalam lansiran sejumlah pemberitaan media online. Sebut saja pada portal berita online Solopos.com (Adhi, 2019), dimana Bupati 
Karanganyar Juliyatmono menyampaikan target pada tahun 2019 dengan program satu desa mempunyai satu hafiz. Hal tersebut disampaikan dalam acara Malam Cinta Rasul 2018 di Alun-Alun Karanganyar. Alasan program ini dicanangkan adalah agar lahir standar baru keislaman di Karanganyar. Dia menginginkan rakyat di Bumi Intanpari, Karanganyar, menjadi lebih islami dan berakhlak Alquran.

Pemberitaan lain mengenai Kabupaten Karanganyar juga merujuk pada program sanitasi yang berhasil dilakukan sejak beberapa tahun terakhir. Capaian tersebut menjadikan Pemerintah Kabupaten Karanganyar menerima sejumlah penghargaan, salah satunya adalah Radar Solo Awards 2018 Kategori Inovasi Sanitasi Total Berbasis Masyarakat (STBM) Berkelanjutan (Aulia, 2018; Jateng, 2018; Sidiq, 2018) Sebelumnya dengan program yang sama, Pemerintah Kabupaten Karanganyar juga merebut peringkat tiga nasional dari Kementerian Kesehatan (Kemenkes). Selanjutnya disusul penghargaan sebagai peringkat kedua sebagai Smart Sanitasi Award Akkopsi 2018 Kategori Kelengkapan National Water Supply and Sanitation Information Services (Nawasis).

Berita selanjutnya diperoleh melalui ulasan pada Harianmerapi.com (2019) yang menjelaskan bahwa Bupati Karanganyar menerima penghargaan dari Dewan Masjid Indonesia (DMI) Propinsi Jawa Tengah. Hal ini terkait dengan gerakan sholat berjamaah keliling yang dicanangkan oleh Pemerintah Kabupaten Karanganyar. Gerakan sholat berjamaah itu dipimpin oleh Bupati Karanganyar dengan sasaran masjid di wilayahnya. Kedatangan Bupati Karanganyar selalu diikuti pemberian bantuan ke takmir dan sebagainya, dilakukan secara random untuk Ashar keliling, Subuh keliling dan Jumat keliling. Bukan itu saja, orang nomor satu di Pemkab Karanganyar juga menggerakkan masyarakat untuk rutin membersihkan masjid.

Selain itu, diberitakan mengenai Bupati Karanganyar, Juliyatmono, yang mendapat penghargaan oleh Persatuan Wartawan Indonesia (PWI) pada acara malam Anugerah Pers Jateng 2019 di Hotel Lorin Colomadu Karanganyar, karena dinilai telah memberikan kontribusi kepada Jawa Tengah sungguh luar biasa. Selain itu, kemitraan wartawan dengan bupati sangat baik (Karanganyar, 2019a; Wardoyo, 2019a).

Sejumlah berita di atas merujuk pada berita dan informasi positif yang diterima oleh Pemerintah Kabupaten Karanganya. Namun demikian, terdapat pula beberapa lansiran berita negatif yang juga ditujukan kepada pemerintah Kabupaten Karanganyar. Salah satunya adalah informasi dengan tune cenderung negatif 
mengenai Program Jamkesda Pemkab Karanganyar yang dinilai tidak mendukung warga miskin. Dalam beritanya, Pemkab Karanganyar menyatakan mencabut atau menyatakan tidak berlaku lagi Jaminan kesehatan daerah (Jamkesda) mulai tahun 2019. Program Jamkesda hanya diperuntukkan pada pembayaran premi penduduk miskin yang diintegrasikan dalam program Jaminan Kesehatan Nasional berbentuk JKNKIS (Wardoyo, 2019b).

Berdasarkan uraian di atas, keberadaan organisasi ataupun lembaga pada dasarnya membutuhkan media massa dalam penyampaian pesannya ke khalayak luas. Hal ini diharapkan agar publikasinya mampu membangun persepsi atau opini yang positif dari khalayak. Masyarakat cenderung akan menilai suatu berita yang dilihatnya sesuai dengan pernyataan yang dilakukan media. Media komunikasi diperlukan karena menjadi sarana yang sangat penting dan efisien dalam berkomunikasi dengan masyarakat. Agar komunikasi dengan publik dapat terpelihara, maka segala kepentingan media massa terhadap organisasi tentunya harus direspons organisasi dengan baik dan menciptakan mutualisme (Iriantara, 2005).

Guna mencari novelty dengan penelitian terdahulu, sejumlah literatur dari penelitian sebelumnya digunakan oleh peneliti sebagai pemetaan dalam merumuskan, sekaligus menguatkan permasalahan. Pertama adalah tulisan Bodro (2016) berjudul Strategi Media Relations dalam Memelihara Citra "Solo: The Spirit Of Java" (Studi Deskriptif Kualitatif pada Bagian Humas dan Protokol SETDA Kota Surakarta), dimana media relations yang digunakan dalam analisis mengarah pada pengelolaan relasi, pengembangan strategi, serta memperluas jaringan dengan media.

Kedua, Azis (2018) dengan tulisan berjudul Strategi Media Relations Hubungan Masyarakat Pemerintah Kabupaten Luwu Timur Sebagai Sarana Informasi Publik. Tulisan ini membahas tentang strategi yang dilakukan oleh humas pemerintahan Kabupaten Luwu Timur sebagai sarana penyampaian informasi publik, yakni dengan menyebarluaskan informasi kepada masyarakat, sekaligus menganalisis adanya hambatan media relations humas Kabupaten Luwu Timur dalam menyebarluaskan informasi.

Ketiga, penelitian dari Aditrianto (2017) berjudul Strategi Media Relations Humas Pemerintah Kabupaten Grobogan dalam Melaksanakan Publisitas (Studi Deskriptif Kualitatif Tentang Strategi Media Relations Humas Pemerintah dalam Melaksanakan Publisitas di Bagian Humas dan Protokol Sekretariat Daerah Kabupaten Grobogan). 
Ditemukan hasil bahwa strategi media relations humas Pemerintah Kabupaten Grobogan dalam melaksanakan publisitas mencakup tiga peran, yaitu: peran humas, peran media relations, dan peran sebagai publikasi informasi atau publisitas. Peran humas yang dilakukan oleh bagian Humas Kabupaten Grobogan telah terlaksana dengan baik, dimana humas telah memerankan fungsinya dalam menjembatani komunikasi antara pemerintah dengan masyarakat.

Selanjutnya adalah penelitian Zaqiyah (2017) mengenai Strategi Humas Kabupaten Karanganyar dalam Upaya Pengembalian Citra Positif (Studi Kasus GLA dan BKK di Kabupaten Karanganyar). Melalui tulisan tersebut, ditemukan hasil analisis bahwa Humas Kabupaten Karanganyar dalam menjalankan strategi peningkatan komunikasi untuk informasi publik dilakukan melalui liputan semua kegiatan yang berhubungan dengan GLA dan BKK.

Adapun penelitian mengenai media relations yang lainnya pada dasarnya dibahas secara beragam. Hal ini berkenaan dengan bagaimana media relations dipandang dan dianalisis menjadi faktor penting dalam memengaruhi sejumlah bidang yang ada pada sebuah lembaga, baik berkaitan dengan citra dan reputasi, kebutuhan dan selera pasar, maupun dalam menunjang kinerja lembaga, salah satunya dalam menyukseskan ataupun menyosialisasikan berbagai program. Sebut saja dalam hal konteks ini, media relations yang dikaitkan dengan citra dan reputasi PDAM oleh (Rahmawati \& Pratiwi, 2019); media relations dalam kaitannya dengan agenda setting media (Syahputra, 2018); media relations dalam instansi pendidikan (Triyono, 2013); media relations dalam kaitannya dengan pelanggan (Ziana, 2018); media relations terhadap upaya penyelesaian krisis perusahaan (Febriyansyah, Christin, \& Imran, 2016); serta media relations dalam kaitannya dengan penggunaan media online korporat perusahaan (Herlina, Widiastuti, Rahmayani, \& Susana, 2018).

Merujuk pada uraian penelitian terdahulu di atas, adanya konteks keterbukaan ataupun transparasi informasi secara utama dipandang sebagai hal penting dalam pelaksanaan sosialisasi informasi publik. Dalam hal ini, keterbukaan merujuk pada keterbukaan dalam melaksanakan suatu proses kegiatan. Lebih lanjut, transparasi informasi merujuk pada keterbukaan pemerintah dalam memberikan informasi yang terkait dengan aktivitas pengelolaan sumber daya publik kepada pihak-pihak yang membutuhkan informasi (Tahir, 2014). 
Berdasarkan sejumlah masalah yang ada, dapat dilihat bahwa dalam sosialisasi program Pemerintah Kabupaten Karanganyar nyatanya perlu ditingkatkan kembali. Pasalnya, masih ada beberapa tempat yang dinilai kurang mendapatkan ketercapaian informasi yang baik karena program digitalisasi informasi yang belum sampai ke arah tersebut. Diskominfo Kabupaten Karanganyar sudah melakukan strategi media relations dalam sosialisasi program Pemkab Karanganyar, yakni melalui media elektronik maupun media cetak guna mewujudkan pertanggung jawaban pemerintah terhadap warganya sebagai bentuk prinsip transparasi (keterbukaan).

Adanya praktik media relations ini, di sisi lain nyatanya juga menemui sejumlah kendala dimana masih muncul pemberitaan negatif atas kinerja dan program pemerintah yang dinilai kurang bersahabat dengan rakyat. Untuk itu, perlu adanya pengembangan atas strategi media relations yang dilakukan agar dapat berjalan secara lebih optiman. Dengan demikian, melalui penyelenggaraan pemerintahan, masyarakat diberikan kesempatan untuk mengetahui kebijakan yang akan telah diambil oleh pemerintah. Sedangkan melalui transparasi penyelenggaraan pemerintahan tersebut, masyarakat juga dapat memberikan feedback terhadap kebijakan yang telah diambil oleh pemerintah.

Berdasarkan uraian di atas, dapat dirumuskan mengenai beberapa hal yang merujuk pada permasalahan dalam penelitian ini. Pertama, belum meratanya akses informasi pada sejumlah wilayah di Kabupaten Karanganyar sehingga menjadi pemicu masalah dalam penelitian ini. Hal ini turut berimbas pada kurang optimalnya sosialisasi informasi publik yang seharusnya dapat diterima dan diakses oleh masyarakat. Kedua, praktik media relations dipandang kurang optimal sehingga relasi antara pemerintah dengan sejumlah media menjadi kurang. Hal selanjutnya yang turut mengikuti adalah masih munculnya pemberitaan negatif di media mengenai pemerintahan, yang pada akhirnya berpengaruh terhadap citra dan reputasi pemerintahan di mata masyarakat.

Kedua identifikasi masalah di atas pada dasarnya mengarah pada bagaimana media relations diharapkan mampu mendukung adanya sosialisasi informasi untuk masyarakat. Dalam konteksnya, dengan menjalin relasi dengan media secara maksimal, pemerintah mampu membangun saluran untuk dapat mempermudah penyampaian informasi kepada masyarakat, terutama pada informasi publik yang memuat sejumlah program pemerintah bagi masyarakat. Melalui adanya relasi yang 
baik dengan media, informasi dapat ditunjang untuk disampaikan secara serentak kepada masyarakat, selain juga mampu menjadikan citra pemerintah menjadi baik di mata masyarakat.

Berdasarkan uraian latar belakang tersebut, dapat dijelaskan bahwa penelitian ini akan diarahkan pada bagaimana konteks media relations Diskominfo Kabupaten Karanganyar dalam melakukan sosialisasi program pemerintah. Adapun penelitian ini selanjutnya diharapkan mampu memberikan penjelasan melalui gambaran strategi serta pelaksanaan media relations Diskominfo Kabupaten Karanganyar sebagai bentuk kinerja komunikasi dari Public Relations pemerintah, terutama dalam kaitannya dengan penyampaian serta sosialisasi sejumlah program pemerintah bagi masyarakat di Kabupaten Karanganyar.

\section{METODE PENELITIAN}

Strategi yang digunakan dalam penelitian ini adalah deskriptif kualitatif, dimana analisis penelitian dilakukan secara kualitatif dengan basis penjelasan secara deskriptif (penggambaran). Penelitian kualitatif dinyatakan sebagai penelitian yang memiliki latar ilmiah, dilakukan dengan tujuan untuk menafsirkan atau mengartikan fenomena yang terjadi, serta dilakukan dengan melibatkan sejumlah metode yang ada (Denzin \& Lincoln, 1994; Moleong, 2007). Penelitian dalam artikel ini secara spesifik bertujuan untuk menggambarkan secara terperinci atas apa yang menjadi jawaban dari permasalahan peneliti. Dalam konteks ini, peneliti bertujuan untuk memberikan pandangan lengkap dan mendalam terkait dengan subjek penelitian yang diteliti (Mulyana, 2001).

Data penelitian merujuk pada data primer yang diperoleh melalui wawancara mendalam kepada informan, serta observasi terkait dengan kegiatan media relations dari Diskominfo Kabupaten Karanganyar. Adapun pengumpulan data melalui wawancara dilakukan secara mendalam (depth interview) dan terstruktur dengan menggunakan pedoman wawancara (interview guide) yang disusun secara sistematis guna menunjang pengumpulan data (Herdiansyah, 2015). Wawancara dilakukan oleh peneliti adalah teknik wawancara mendalam (depth interview). Wawancara mendalam adalah suatu cara mengumpulkan data atau informasi secara langsung bertatap muka dengan informan agar mendapatkan data lengkap dan mendalam. 
Terkait wawancara mendalam yang dilakukan, informan yang pada penelitian ini secara khusus ditujukan pada bagian pengelolaan website dan media Diskominfo Kabupaten Karanganyar. Lebih jelas, narasumber yang menjadi informan dalam penelitian ini adalah: 1) Kepala Diskominfo Kabupaten Karanganyar dalam kaitannya sebagai kepala yang membawahi pengelolaan website dan media; 2) Kepala Sub Bagian Bidang Informasi dan Komunikasi Publik (IKP) sebagai pelaksana kebijakan, peliputan, pengelola informasi, dan pelaporan opini publik; serta 3) Kepala Seksi Pengembangan Sistem Informasi Manajemen sebagai pihak pelaksana kebijakan, pemantauan, evaluasi, dan pelaporan pengembangan pada sistem informasi manajemen.

Pengumpulan data selanjutnya adalah observasi, yakni suatu kegiatan mencari data yang dapat digunakan untuk memberikan suatu kesimpulan atau diagnosis. Dalam observasi ini, peneliti terlibat dalam kegiatan yang sedang diamati, meski tidak secara active participant. Peneliti juga mencatat beberapa hal yang diamati untuk selanjutnya menjadi bahan untuk reduksi data selanjutnya. Sedangkan untuk data sekunder, data diperoleh dengan dokumentasi ataupun studi literatur atas sejumlah referensi yang ada, seperti: buku, jurnal atau artikel ilmiah, foto, laporan berita, sumber-sumber online, dan beberapa arsip atau dokumen pendukung dari Diskominfo Kabupaten Karanganyar.

Guna memeriksa validitas data, teknik triangulasi yang digunakan adalah triangulasi sumber, dimana data diperoleh dari beberapa sumber yang berbeda guna mencari kesamaan data. Selanjutnya, untuk teknik analisis data yang digunakan adalah teknik analisis data interaktif dari Miles dan Huberman. Dalam konteks ini, data dianalisis secara interaktif dan terus menerus sehingga diperoleh kejenuhan data, yakni melalui tahapan reduksi data, penyajian data, dan penarikan kesimpulan (verifikasi data) (Sugiyono, 2018).

\section{HASIL PENELITIAN DAN PEMBAHASAN}

Dinas Komunikasi dan Informatika (Diskominfo) Kabupaten Karanganyar beralamatkan di Jalan Lawu No. 385 B Karanganyar, tepatnya di Gedung B Lantai 1, Kantor Sekretariat Daerah Kabupaten Karanganyar. Berdasarkan Peraturan Daerah Nomor 16 Tahun 2016 tentang Pembentukan dan Susunan Perangkat Daerah 
Kabupaten Karanganyar, dibentuklah Organisasi Perangkat Daerah (OPD) sebanyak 40 OPD, salah satunya Diskominfo Kabupaten Karanganyar.

Diskominfo Kabupaten Karanganyar merupakan satuan dinas tipe C yang dipimpin oleh Kepala Dinas dan berada di bawah, sekaligus bertanggung jawab langsung kepada Bupati. Terkait tugas dan fungsi Diskominfo ini, berdasarkan Peraturan Bupati Nomor 111 Tahun 2016, tentang Kedudukan, Susunan Organisasi, Tugas, Fungsi dan Tata Kerja Dinas Komunikasi dan Informatika, Diskominfo Kabupaten Karanganyar bertugas untuk membantu Bupati dalam melaksanakan urusan pemerintahan bidang komunikasi dan informasi, bidang persandian dan bidang statistik, yang menjadi kewenangan daerah dan tugas pembantuan yang ditugaskan kepada daerah.

Secara struktural dalam menjalankan tugasnya, Kepala Diskominfo Kabupaten Karanganyar dibantu oleh sejumlah bagian yang dibawahinya, antara lain adalah: 1) Sekretaris (Sub Bagian Umum dan Kepegawaian dan Sub Bagian Perencanaan dan Keuangan); 2) Bidang Tata Kelola Informatika (Seksi Pengembangan Sistem Informasi Manajemen, Seksi Persandian dan Keamanan Jaringan, dan Seksi Pengelolaan $e$ Government); 3) Bidang Informasi dan Komunikasi Publik (Seksi Pengelolaan Media dan Data Statistik, Seksi Pengelolaan Daya Komunikasi dan Informatika, dan Seksi Pelayanan Informasi Publik).

Visi Diskominfo Kabupaten Karanganyar pada dasarnya ditetapkan dengan mempertimbangkan tugas dan fungsi, serta Rencana Jangka Menengah Daerah Kabupaten Karanganyar. Adapun visi dari Diskominfo Kabupaten Karanganyar adalah "Kabupaten Karanganyar Maju Berbasis Teknologi Informasi". Visi ini selanjutnya diuraikan melalui sejumlah misi yang merepresentasikan tugas pokok dan fungsi Diskominfo sebagai suatu organisasi. Selanjutnya untuk misi Diskominfo Kabupaten Karanganyar, adalah sebagai berikut: 1) Mewujudkan Pemerintah Kabupaten Karanganyar Berbasis Teknologi Informasi Melalui Optimalisasi Sumberdaya Aparatur; 2) Mewujudkan Masyarakat Kabupaten Karanganyar Cerdas Melalui Fasilitasi Sarana Prasarana Teknologi Informasi Bagi Seluruh Lapisan Anggota Masyarakat; 3) Mewujudkan Masyarakat Kabupaten Karanganyar Berwawasan Informasi Melalui Optimalisasi Diseminasi Informasi Dan Komunikasi Publik. 
Tugas dan fungsi Diskominfo Kabupaten Karanganyar secara garis besar berkenaan dengan urusan pemerintahan dalam bidang komunikasi dan informasi, selain juga mengelola bidang persandian dan statistik sebagai bentuk pengelolahan dan sumber data bagi Pemda Karanganyar. Lebih lanjut, secara operasional, tugas dan fungsi yang dapat dijalankan oleh Diskominfo Kabupaten Karanganyar adalah: 1) merumuskan kebijakan teknis di bidang komunikasi dan informasi, persandian, statistik dan kesekretariatan; 2) melakukan koordinasi kebijakan komunikasi dan informasi, persandian dan statistik; 3) melaksanakan kebijakan bidang komunikasi dan informasi, persandian dan statistik; 4) melakukan evaluasi dan pelaporan bidang komunikasi dan informasi, persandian dan statistik; 5) melaksanaan fungsi kesekretariatan dinas; 6) mengendalikan penyelenggaraan tugas UPTD; serta 7) melaksanakan tugas lain, sesuai dengan tugas dan fungsinya.

\section{Bentuk Media Relations}

Hubungan yang terjalin bersama pers atau media, pada dasarnya merupakan alat pendukung yang digunakan untuk kerja sama atas kepentingan proses publikasi dan publisitas berbagai kegiatan program kerja. Hal ini dimaksudkan untuk menunjang kelancaran aktivitas komunikasi humas dengan publik. Selain itu, hal ini berkenaan dengan salah satu fungsi pers sebagai kekuatan pembentuk opini publik yang sangat efektif melalui media massa (Ruslan, 2006).

Strategi media relations dalam suatu pemerintahan salah satunya, dipandang sangat penting, terutama di era modern saat ini. Sebut saja untuk Diskominfo Kabupaten Karanganyar yang memiliki tugas sekaligus bertanggung jawab atas penyedia informasi terkait program kegiatan dari Kabupaten Karanganyar tentunya harus mampu bekerja sama dengan baik bersama awak media. Dalam konteks ini, kerja sama dan hubungan yang terjalin dimaksudkan untuk membantu publikasi informasi seputar program yang ada di Kabupaten Karanganyar. Lebih lanjut, dalam kepentingan ideal pemerintah, follow up dari hubungan baik ini mampu meningkatkan serta menambah citra baik Kabupaten Karanganyar.

Menanggapi uraian di atas, Diskominfo Kabupaten Karanganyar perlu untuk menjalin kerjasama yang baik dengan media massa, terutama yang berada di sekitar Pemerintah Kabupaten Karanganyar. Kerjasama dengan pers akan menghasilkan 
frekuensi publisitas yang cukup tinggi sehingga dampaknya, publik dapat mengetahui informasi dalam waku yang singkat dan cakupan wilayah yang luas. Secara teknis, Diskominfo Kabupaten Karanganyar memang memerlukan kerja sama dengan pihak media massa guna membantu menyosialisasikan program-program Pemerintah Kabupaten Karanganyar. Adapun kerjasama yang dilakukan Diskominfo Kabupaten Karanganyar dengan berbagai media massa ini merujuk pada kerja sama dengan jenis media cetak maupun elektronik. Asumsinya, media massa merupakan saluran penyampaian pesan yang dapat mencapai sejumlah besar massa yang heterogen dalam waktu yang cepat.

Lebih jelas, aktivitas media relations yang dilakukan oleh Diskominfo Kabupaten Karanganyar mempunyai peran dan fungsi sebagai penghubung antara pemerintah dengan publik melalui media massa. Dalam hal ini, bentuk aktivitas media relations yang dilakukan, meliputi: press conference, press release, press tour, press gathering, dan media visit.

1. Press conference

Press Conference Diskominfo Kabupaten Karanganyar secara teknis dilakukan dengan mengundang sekelompok wartawan dari berbagai media untuk berkumpul guna mendapatkan informasi secara langsung. Press conference sering kali dilangsungkan sebelum atau sesudah mengadakan suatu acara yang bersifat resmi, dengan menyampaikan informasi-informasi penting, event tertentu dengan topik yang sedang hangat-hangatnya, maupun menjelaskan suatu masalah yang sedang terjadi sebagai bentuk klarifikasi. Dalam kegiatan press conference, Diskominfo Kabupaten Karanganyar juga menyertakan adanya press release untuk narasumber dan pers yang bertujuan untuk menguatkan hasil dari kegiatan press conference. Dengan demikian, informasi yang diberikan akan menjadi lebih jelas dan diharapkan pers dapat mempublikasikannya kepada masyarakat.

2. Press tour

Press tour ini merupakan kegiatan media relations yang dilakukan oleh Diskominfo Kabupaten Karanganyar dengan mengajak sejumlah wartawan untuk bersama dengan Pemerintah mengunjungi suatu peresmian atau eventevent tertentu yang berhubungan dengan pemerintah. Dalam konteks ini, para wartawan akan merasa diikutsertakan dalam sejumlah kegiatan pemerintah 
sehingga keberadaannya menjadi lebih terasa sebagai pihak yang akrab dengan pemerintah.

3. Press gathering

Diskominfo Kabupaten Karanganyar melakukan upaya untuk mewujudkan hubungan harmonis dengan media, salah satunya dengan melakukan press gathering dengan para wartawan. Kegiatan press gathering ini mengarah pada menyediakan waktu khusus untuk dapat berkumpul bersama wartawan dengan tujuan untuk menambah keakraban dan refreshment antara wartawan dengan pegawai pemerintahan.

4. Media visit

Media visit sangat mempengaruhi pola kerja pegawai Diskominfo Kabupaten Karanganyar. Adapun kegiatan media visit dilakukan dengan cara berkunjung ke beberapa lembaga media secara berkala.

5. Press release

Press Release sebagai publisitas merupakan media yang banyak digunakan untuk menyebarkan berita atau informasi kegiatan seputar Pemerintah Kabupaten Karanganyar. Secara teknis, setelah melakukan peliputan kegiatan, tim liputan rutin akan mengunggah data hasil dari liputan yang diolah dalam bentuk press release melalui web Pemerintah Kabupaten Karanganyar. Press release yang dibuat oleh tim liputan ini yang ditujukan kepada masyarakat agar mudah dimengerti isinya serta mengetahui informasi maupun seputar kegiatan yang ada di Kabupaten Karanganyar. Lebih lanjut, keberadaan press release ini juga mampu menjadi pendukung dalam kegiatan media relations Diskominfo Kabupaten Karanganyar yang lainnya, salah satunya press conference.

Sosialisasi program pemerintah atau menyebarluaskan informasi tidak akan terealisasikan tanpa adanya kerja sama dengan awak media. Maka dari itu, Diskominfo melakukan berbagai cara untuk dapat sosialisai program agar tercapainya tujuan organisasi. Salah satunya adalah terus gencar melakukan kegiatan-kegiatan yang dapat meningkatkan kepercayaan publik serta membangun opini publik yaitu dengan melakukan kegiatan-kegiatan seperti melakukan sosialisasi program dalam acara kegiatan-kegiatan tertentu seperti halnya wayangan, festival-festival dan lain sebagainya yang dapat membesarkan nama Pemerintah Kabupaten Karanganyar. 


\section{Strategi Mengelola Relasi}

Strategi media relations yang pertama adalah dengan mengelola relasi, dimana mengelola relasi di sini dilakukan secara operasional dengan menjalin hubungan dengan media. Bagi sebuah instansi ataupun lembaga pemerintahan, adanya peran media terhadap lembaga dirasa menjadi hal yang utama dan penting untuk dimiliki. Terlebih, di era digital dan perkembangan teknologi, banyaknya media yang bermunculan menjadi salah satu peluang agar lembaga atau instansi memiliki eksistensi melalui relasi yang dibangun bersama dengan media. Salah satunya dapat dilihat dari pemanfaatan media sosial sebagai platform media dalam mendukung relasi dan komunikasi dengan media-media yang diajak kerja sama. Berikut penuturan dari Ardiansyah Kepala Sub Bagian Kepala Bidang Informasi dan Komunikasi Publik (IKP):

Saat ini yang paling mudah menyampaikan publikasi informasi efektif melalui media sosial, yang saat ini kita dorong informasi apapun di media sosial ("Personal Interview Kepala Sub Bagian Bidang Informasi dan Komunikasi Publik (IKP),” 2019).

Pernyataan informan di atas secara tidak langsung menyatakan pentingnya penggunaan media sosial dalam penyaluran informasi. Lebih jauh, adanya informasi yang disampaikan selanjutnya dapat diteruskan untuk menjadi bahan bagi para media dalam menghimpun pemberitaan.

Diskominfo Kabupaten Karanganyar gencar melakukan berbagai cara untuk melakukan sosialisasi program Pemerintah Karanganyar bagi masyarakat. Salah satunya adalah dengan menjalin kerjasama dengan beberapa media massa, baik itu media lokal maupun media skala nasional. Media yang sudah bekerjasama dengan pemerintah Kabupaten Karanganyar yang secara terikat meliputi media dari Solopos, Radarsolo, Suara Merdeka, Tribun Jateng, Jateng Pos, TATV dan lain sebagainya. Hal ini didukung oleh penuturan Ardiansyah selaku Kepala Sub Bagian Kepala Bidang Informasi dan Komunikasi Publik (IKP).

Media itu kan menjadi patner kita dalam melaksanakan publikasi sehingga perlu dijalin komunikasi, koordinasi baik dengan media yang ada sehingga informasi apapun yang ada di Kabupaten Karanganyar bisa di bantu dipublikasikan dengan media massa yang ada di Kabupaten Karanganyar. Semua media ada sekitar 25 media yang bekerja sama, ada media cetak yaitu radar solo, solopos, tribun jateng, jateng pos, suara merdeka, dan media online ada timlo.net, suara merdeka, tribun, TATV dan lain sebagainya ("Personal Interview Kepala Sub Bagian Bidang Informasi dan Komunikasi Publik (IKP)," 2019).

Di situlah kita dapat mengetahui bahwa peran media sangatlah penting bagi instansi. Dalam kegiatan media relations, instansi ataupun lembaga secara tidak 
langsung dituntut untuk menjaga jaringan dengan media agar relasi dapat terjaga dengan baik. Hal ini disampaikan oleh Ardiansyah Kepala Sub Bagian Kepala Bidang Informasi dan Komunikasi Publik (IKP) :

Media itu kan menjadi patner kita dalam melaksanakan publikasi sehingga perlu dijalin komunikasi, koordinasi baik dengan media yang ada sehingga informasi apapun yang ada di Kabupaten Karanganyar bisa di bantu dipublikasikan bersama dengan media massa yang ada di Kabupaten Karanganyar" ("Personal Interview Kepala Sub Bagian Bidang Informasi dan Komunikasi Publik (IKP)," 2019).

Guna menjalankan upaya untuk membangun hubungan pers, Diskominfo Kabupaten Karanganyar melakukan berbagai kegiatan yang berkaitan dengan pers. Melalui penyelenggaraan press conference, yaitu kegiatan tersebut merupakan kegiatan yang bertujuan untuk menyampaikan informasi-informasi penting, event dengan topik yang sedang hits, menjelaskan suatu masalah yang sedang terjadi sebagai bentuk klarifikasi.

Guna menjalankan tugasnya, Diskominfo Kabupaten Karanganyar memiliki tim media di dalam pelaksanaan menjalin hubungan dengan para wartawan yaitu Sub Bagian Bidang Informasi dan Komunikasi Publik (IKP). Dalam mengelola relasi, kegiatan media relations yang dilakukan Diskominfo Kabupaten Karanganyar tidak hanya terbatas pada kegiatan informal di dalam ruangan atau meja kerja, melainkan juga melalui kegiatan media relations dengan mengajak para wartawan untuk kegiatan diluar ruangan yang bersifat lebih santai dan untuk pengakraban seperti press gathering. Media visit yang juga kerap dilakukan oleh Diskominfo Karanganyar dengan wartawan yang bekerjasama dengan Pemkab Karanganyar. Hal ini salah satunya bertujuan untuk mempengaruhi pola kerja pegawai Diskominfo Kabupaten Karanganyar dengan media, yaitu dengan cara mengunjungi media-media secara berkala sehingga mampu menciptakan upaya dalam meningkatkan hubungan harmonis dengan media.

Merujuk pada sejumlah dokumentasi di atas, terlihat Diskominfo Kabupaten Karanganyar bersama sejumlah awak media yang bertugas di Karanganyar, mengunjungi kantor redaksi media lokal di Bali, yaitu Bali Post. Adapun kunjungan tersebut membahas perihal kerja sama antara media dan pemerintah daerah. Melalui kerja sama tersebut, pemerintah diberi ruang untuk mengenalkan potensi daerah masing-masing dengan porsi tetap berimbang dalam memberitakan dan berpegang pada kode etik jurnalistik. Semua kegiatan dilakukan agar hubungan baik dengan 
media tetap terjaga, sekaligus memeroleh keuntungan antara kedua pihak. Pemerintah melalui Diskominfo Kabupaten Karanganyar mampu memeroleh publikasi melalui media, sedangkan media mendapatkan sumber informasi yang dapat diolah menjadi berita.

Mengenai upaya dalam mengelola relasi ini, Sambo (2019) menyatakan sejumlah prinsip umum yang digunakan untuk membina hubungan atau relasi yang baik dengan pihak pers, mulai dari memberikan pelayanan prima bagi media, sampai dengan bagaimana caranya menjadi pihak yang dapat dipercaya oleh media. Terkait hal ini, berdasarkan temuan data yang diperoleh selama penelitian, dapat dijelaskan bahwa pengelolaan relasi Diskominfo Kabupaten Karanganyar, antara lain adalah:

\section{By Serving The Media}

Memberikan pelayanan kepada media dengan memfasilitasi dan menransparasi segala sesuatu yang berkaitan dengan sosialisasi dan selalu berkomunikasi dengan baik. Semisal, ada berita penting mengenai kendala suatu hal dan menyangkut masyarakat, maka Diskominfo Kabupaten Karanganyar bertanggung jawab untuk memberikan informasi kepada media agar seluruh masyarakat dapat menjangkaunya. Meski dalam hal ini, ada beberapa informasi yang memang tidak dapat diberitakan ataupun dibagikan secara luas. Uraian ini sesuai dengan penuturan Bachtiar Syarif selaku Kepala Diskominfo Kabupaten Karanganyar.

Kami akan menyampaikan informasi para media atau wartawan, jika ada suatu hal, Tugas kami memfasilitasi, Tugas kami adalah menyampaikan kepada masyarakat. Transparasi apapun yang menyangkut sosialisasi pelaksanaan itu sehingga ketika ada kendala kami sebenarnya, kendala apapun kondisi-kondisi saat ini harus kita sampaikan apa yang kita dapat hari itu juga. Apa yang kita miliki kita gunakan secara maksimal, idealnya pemerintah pusat prinsipnya adalah keterjangkauan pada seluruh lapisan masyarakat mengerti apa yang terjadi ("Personal Interview Kepala Dinas Komunikasi dan Informatika (Diskominfo) Kabupaten Karanganyar," 2019).

\section{By Establising A Reputation For Reliability}

Diskominfo Kabupaten Karanganyar selalu menegakkan reputasi agar mendapatkan kepercayaan dari awak media. Dalam konteks ini, Diskominfo Kabupaten Karanganyar selalu menyiapkan bahan informasi akurat agar layak untuk dipublikasikan yang mempunyai nilai berita bagi media sebagai sebuah produk jurnalistik, dengan sumber data atau berita yang jelas, valid, serta bisa dipertanggung jawabkan dan layak untuk diberitakan. Dengan demikian, hubungan dengan media 
akan tetap terjalin dengan baik. Hal ini sejalan dengan pernyataan Ardiansyah, Kepala Sub Bagian Kepala Bidang Informasi dan Komunikasi Publik (IKP):

Jurnalistik itu kan ada kode etiknya tersendiri, kita dalam merelease berita itu tidak lepas dari hal tersebut. Makanya kode-kode etik jurnalistik itu harus kita jadikan pedoman jangan sampai informasi yang di informasikan menjadikan informasi yang salah. Sebagai misal setiap produk jurnalistik itu harus ada sumber data atau beritanya yang jelas, valid dan bisa di pertanggung jawabkan, tidak bisa kita menulis berita itu kita tulis tanpa ada sumbernya tidak bisa, makanya informasi yang diberikan itu harus sesuai dengan kode jurnalistik sesuai yang ada ("Personal Interview Kepala Sub Bagian Bidang Informasi dan Komunikasi Publik (IKP)," 2019).

\section{By Supliying Good Copy}

Upaya Diskominfo Kabupaten Karanganyar untuk menjalin hubungan media, salah satunya adalah dengan memberikan informasi yang baik, sesuai dengan kebutuhan media, dan menarik perhatian. Hal ini diharapkan mampu menjadi salah satu pertimbangan agar informasi yang disediakan dan disalurkan oleh Diskominfo Kabupaten Karanganyar dapat dijadikan sumber berita yang baik, mampu diolah oleh wartawan dengan baik, sekaligus memiliki esensi yang kuat untuk layak dikelola sebagai pemberitaan. Selain itu, Diskominfo Kabupaten Karanganyar juga menyediakan informasi berupa foto ataupun gambar yang dapat digunakan sebagai pendukung data berita.

\section{By Cooperation in Providing Material}

Membangun relasi dengan pihak pers dapat dilakukan dengan menyediakan sejumlah kebutuhan para jurnalis, salah satunya informasi ataupun data yang diperlukan sebagai bahan untuk menulis berita. Dalam hal ini, wartawan diberikan kesempatan untuk wawancara langsung bersama narasumber, terutama terkait dengan narasumber dari Diskominfo Kabupaten Karanganyar, sesuai dengan kebutuhan data yang diperlukan oleh para wartawan media.

\section{By Providing Verification Facilities}

Relasi dapat dibangun, salah satunya dengan memberikan fasilitas bagi media. Pada konteks ini, fasilitas tidak dimaknai sebagai suap ataupun hal sejenis, melainkan memberikan fasilitas guna memudahkan wartawan melakukan peliputan. Sebut saja dengan keberadaan press room yang dilengkapi dengan fasilitas internet dan ruangan yang nyaman untuk menunjang kebutuhan wartawan. 


\section{By Building Personal Relationship with The Media}

Membangun hubungan dengan media, dilengkapi dengan kecanggihan teknologi informasi, pada dasarnya sangat membantu menjalin hubungan personal dengan para awak media. Adapun relasi yang dibangun secara personal ini dilakukan dengan menggunakan grup Whatsapp dan media aneka media sosial lainnya sehingga sehingga hubungan yang terjalin dengan media menjadi semakin erat, akrab, dan saling menghormati dan menghargai antar profesi masing-masing. Adanya relasi yang dibangun secara personal pada akhirnya turut memudahkan Diskominfo Kabupaten Karanganyar untuk menjalin komunikasi terkait dengan keperluan undangan bagi wartawan apabila pihak Pemerintah Kabupaten Karanganyar akan melaksanakan sejumlah kegiatan ataupun acara.

Melalui media relations ini, Pemerintah Kabupaten Karanganyar berharap berita yang dimuat oleh media bisa membantu dalam sosialisasi program pemerintah yang dapat membesarkan nama Pemerintah. Dengan demikian, hubungan antara pihak Instansi dengan media harus tetap harmonis. Sampai saat ini hubungan antara media dengan Diskominfo Kabupaten Karanganyar terjalin dengan baik sehingga tidak pernah ada konflik antara keduanya. Hal ini membawa pengaruh baik untuk keduanya, dimana wartawan selalu meliput semua kegiatan serta memeroleh berbagai informasi tentang program pemerintah, sebaliknya pihak Diskominfo Kabupaten Karanganyar mampu mencapai publikasi dengan baik kepada masyarakat.

\section{Mengembangkan Strategi dan Jaringan dengan Media}

Setelah hubungan dengan relasi terjalin dengan baik, langkah selanjutnya yang dilakukan adalah dengan mengembangkan strategi. Pengembangan strategi media relations pada dasarnya bertujuan untuk mencapai tingkat kesadaran, mengubah sikap, serta mendorong tindakan publik pada sebuah instansi. Namun demikian, pengembangan ataupun inovasi dari pelaksanaan strategi media relations ini tentu harus dimodifikasi dari waktu ke waktu agar sesuai dengan perkembangan instansi serta lingkungan yang melingkupinya.

Salah satu strategi media relations melalui jaringan media adalah dengan menjalin kerja sama dengan media serta instansi daerah lain. Dalam konteks ini, kerja sama daerah adalah sarana untuk memantapkan hubungan dan keterikatan daerah satu dengan yang lainnya dalam kerangka Negara Kesatuan Republik Indonesia, 
menyerasikan pembangunan daerah, mensinergikan potensi antardaerah, dan meningkatkan pengetahuan serta teknologi sebagai bentuk jejaring kerjasama antar instansi (lembaga). Rujukan selanjutnya, adanya jejaring yang dibangun ini mampu mewujudkan adanya kerja sama yang efektif sekaligus produktif antardaerah sebagai solusi alternatif dalam meningkatkan kesejahteraan rakyat dalam mengembangkan konsep pelayanan publik. Sebut saja salah satunya dengan melakukan pengelolaan dan pemanfaatan sumber daya pada Kerjasama Antardaerah dalam lingkup SOBOSUKOWONOSRATEN, yang meliputi Kota Solo, Kabupaten Boyolali, Kabupaten Sukoharjo, Kabupaten Wonogiri, Kabupaten Sragen, Kabupaten Karanganyar, dan Kabupaten Klaten. Adapun kerjasama ini meliputi bidang ekonomi, sosial, budaya, fisik dan sarana prasarana, pengembangan dan penelitian IPTEK, serta bidang lainnya yang telah disepakati.

Selanjutnya, Kerjasama Antardaerah yang disebut sebagai KARISMAPAWIROGO, meliputi wilayah Kabupaten Karanganyar, Kabupaten Wonogiri, Kabupaten Sragen, Kabupaten Magetan, Kabupaten Pacitan, Kabupaten Ngawi, dan Kabupaten Ponorogo. Dalam konteks ini, kerja sama dikaitkan dalam sejumlah bidang, seperti: bidang kesehatan, bidang pertambangan dan energi, bidang kehutanan dan perkebunan, bidang industri dan perdagangan, bidang investasi, bidang ketenagakerjaan, bidang pendidikan dan kebudayaan, bidang sosial, bidang tata ruang dan batas wilayah, bidang pekerjaan umum, bidang perhubungan, bidang lingkungan hidu, bidang pariwisata, bidang pengembangan IPTEK, serta bidang lainnya yang disepakati bersama.

Selain itu, Pemerintah Kabupaten Karanganyar juga bekerjasama dengan Pemerintah Kota Batam, terutama dalam program kerja sama di bidang promosi wisata, perindustrian dan perdagangan. Dengan adanya kerjasama ini, diharapkan hubungan sejumlah daerah mampu mengembangkan sumber daya masing-masing guna menciptakan sinergi usaha yang baik serta saling menguntungkan sejumlah pihak. Lebih lanjut, adanya kerjasama tersebut diharapkan memunculkan adanya peluang bagi kehadiran media untuk dapat turut serta dalam upaya sosialisasi program pada masing-masing lembaga (instansi) yang terkait. 


\section{KESIMPULAN DAN SARAN}

\section{Kesimpulan}

Berdasarkan dari hasil penelitian mengenai strategi Media Relations yang digunakan Dinas Komunikasi dan Informatika (Diskominfo) Kabupaten Karanganyar dalam sosialisasi program terkait dengan Strategi Media Relations yang dilakukan pertama adalah dengan mengelola relasi dimana menjalin kerjasama dengan media cetak maupun media elektronik seperti Solopos, Radar Solo, Suara Merdeka, Tribun Jateng, TATV serta manjalin hubungan baik dengan media dari manapun yang diimplementasikan melalui bentuk-bentuk strategi media relations yaitu Press Conference, Press Tour, Press Release, Media visit, Press Gathering. Diskominfo Kabupaten Karanganyar telah melalukan komunikasi dengan baik dengan wartawan yang bekerjasama dengan Pemkab Karanganyar.

Strategi media relations yang kedua adalah mengembangkan strategi dengan bekerjasama dengan daerah lain salah satunya yaitu dengan Pemkot Batam dengan meningkatkan kesejahteraan rakyat dalam mengembangkan konsep pelayanan publik, serta optimalisasi pengelolaan dan pemanfaatan sumber daya alam. Strategi media relations yang ketiga yaitu mengembangkan jaringan yaitu Diskominfo Kabupaten Karanganyar tidak hanya menjalin kerjasama dengan media lokal saja namun juga media skala nasional seperti JatengNews.net dan InfoPublik.id. Dengan begitu diketahui bahwa masing-masing peran sudah menjalankan fungsinya dengan baik sehingga tujuan dari kedua belah pihak dapat tercapai.

\section{Saran}

Diharapkan penelitian ini bisa dijadikan sebagai referensi untuk mengembangkan penelitian selanjutnya mengenai media relations, sosialisasi program, atau penelitian selanjutnya bisa lebih kepada level komunikasi organisasi yang dilakukan. Selanjutnya secara praktis, Diskominfo Kabupaten Karanganyar agar lebih banyak lagi dalam penyaringan pegawai agar dapat memahami IT dan dapat mengikuti perkembangan IT nantinya, sehingga dapat memaksimalkan kinerja dalam menjalin hubungan dengan media sehingga sosialisasi program akan tercapai sesuai dengan apa yang diharapkan 


\section{DAFTAR PUSTAKA}

Adhi, I. S. (2019). Resolusi Karanganyar 2019: 1 Desa Harus Ada 1 Hafiz. Retrieved from https://www.solopos.com/resolusi-karanganyar-2019-1-desa-harus-ada-1hafiz-962154

Aditrianto, R. (2017). Strategi Media Relations Humas Pemerintah Kabupaten Grobogan Dalam Melaksanakan Publisitas (Studi Deskriptif Kualitatif Tentang Strategi Media Relations Dalam Melaksanakan Publisitas Di Bagian Humas Dan Protokol Sekretariat Daerah Kabupaten Grobogan). Universitas Muhammadiyah Surakarta. Retrieved from http:/ / eprints.ums.ac.id/51672/

Aulia, Y. (2018). Kabupaten Karanganyar Menerima Penghargaan STBM Berkelanjutan. $\quad$ Retrieved from https://jateng.tribunnews.com/2018/10/18/kabupaten-karanganyar-menerimapenghargaan-stbm-berkelanjutan

Azis, A. (2018). Strategi Media Relation Hubungan Masyarakat Pemerintah Kabupaten Luwu Timur sebagai Sarana Informasi Publik. Universitas Islam Negeri Alauddin Makassar. Retrieved from http:/ / repositori.uin-alauddin.ac.id/8635/

Bodro, J. S. (2016). Strategi Media Relations dalam Memelihara Citra "Solo: The Spirit Of Java" (Studi Deskriptif Kualitatif pada Bagian Humas dan Protokol SETDA Kota Surakarta). IAIN Surakarta. Retrieved from http://eprints.iainsurakarta.ac.id/458/1/Setyo Bodro.pdf

Denzin, N. K., \& Lincoln, Y. S. (1994). Handbook of Qualitative Research. London: Sage Publication Inc.

Effendy, O. U. (1986). Hubungan Masyarakat: Suatu Studi Komunikasi. Bandung: PT Remaja Rosdakarya.

Febriyansyah, A. R., Christin, M., \& Imran, A. I. (2016). Strategi Media Relations PR Pelabuhan Tanjung Priok dalam Menanggapi Krisis. Jurnal Kajian Komunikasi, 4(2), 229-242.

Harianmerapi.com, A. (2019). Bupati Karanganyar Dapat Penghargaan DMI. Retrieved from https://www.harianmerapi.com/solo/2019/01/06/48126/bupatikaranganyar-dapat-penghargaan-dmi

Herdiansyah, H. (2015). Wawancara, Observasi, dan Focus Groups: Sebagai Instrumen Penggalian Data Kualitatif. Jakarta: PT Raja Grafindo Persada.

Herlina, R., Widiastuti, N., Rahmayani, R., \& Susana, E. (2018). Manfaat Internet Corporate sebagai Media Relations Hotel Java Retro \& Suites. Jurnal Abdimas BSI: Jurnal Pengabdian Kepada Masyarakat, 2(1), 32-39.

Iriantara, Y. (2005). Media Relations: Konsep, Pendekatan dan Praktik. Bandung: Simbiosa Rekatama Media.

Jateng, Y. P. (2018). Bupati Karanganyar Terima Penghargaan Tokoh Inovasi STBM. Retrieved from https://jatengprov.go.id/beritadaerah/bupati-karanganyarterima-penghargaan-tokoh-inovasi-stbm/

Jefkins, F. (1995). Public Relations. Jakarta: Penerbit Erlangga.

Karanganyar, D. K. (2019a). Bupati Karanganyar Terima Anugerah dari PWI. Retrieved March 16, 2019, from http://www.karanganyarkab.go.id/20190316/bupatikaranganyar-terima-anugerah-dari-pwi/ 
Karanganyar, D. K. (2019b). Dokumen Bidang Informasi dan Komunikasi Publik (IKP). Karanganyar.

Moleong, L. J. (2007). Metodologi Penelitian Kualitatif. Bandung: PT Remaja Rosdakarya.

Mulyana, D. (2001). Metode Penelitian Kualitatif: Paradigma Baru Ilmu Komunikasi dan Ilmu Sosial. Bandung: PT Remaja Rosdakarya.

Personal Interview Kepala Dinas Komunikasi dan Informatika (Diskominfo) Kabupaten Karanganyar. (2019). Karanganyar.

Personal Interview Kepala Sub Bagian Bidang Informasi dan Komunikasi Publik (IKP). (2019). Karanganyar.

Rahmawati, \& Pratiwi, R. Z. B. (2019). Strategi Media Relations PDAM Surakarta dalam Upaya Mempertahankan Citra Perusahaan. Lentera: Jurnal Ilmu Dakwah Dan Komunikasi, 3(1), https:// doi.org/https:/ / doi.org/10.21093/lentera.v3i1.1638

41-63.

RI, D. P. R. (DPR) dan P. Undang-undang Republik Indonesia Nomor 32 Tahun 2004 tentang Pemerintah Daerah (2004). Indonesia. Retrieved from https://www.dpr.go.id/dokjdih/document/uu/33.pdf

Ruslan, R. (2006). Manajemen Public Relations dan Media Komunikasi (Konsepsi dan Aplikasi). Jakarta: PT Raja Grafindo Persada.

Sambo, M. (2019). Media Relations Kontemporer. Jakarta: Prenadamedia Group.

Sidiq, F. H. (2018). Karanganyar Raih Penghargaan STBM dari Kemenkes. Retrieved from https://www.posjateng.id/warta/karanganyar-raih-penghargaan-stbmdari-kemenkes-b1U7w9ca

Siregar, E. L. (2018). Diskominfo Karanganyar Ajak Wartawan Karanganyar Kunjungi Redaksi Bali Post. Retrieved from https://solo.tribunnews.com/2018/10/26/diskominfo-karanganyar-ajakwartawan-karanganyar-kunjungi-redaksi-bali-post.

Sugiyono. (2018). Metode Penelitian Kuantitatif, Kualitatif, dan RED. Bandung: Alfabeta.

Syahputra, I. (2018). Strategi Media Relations Perusahaan Pertambangan Timah dan Agenda Setting Media di Bangka Belitung. Jurnal Kajian Komunikasi, 6(1), 91-105.

Tahir, A. (2014). Kebijakan Publik dan Transparasi Penyelenggaraan Pemerintah Daerah. Bandung: Alfabeta.

Triyono, A. (2013). Strategi Media Relations Perguruan Tinggi di Surakarta (Studi di Universitas Muhammadiyah Surakarta dan Universitas Sebelas Maret). KomuniTi, $5(1)$.

Tulung, F. H. (2014). Berkomunikasi Di Ruang Publik: Implementasi Kehumasan Pemerintah. Jakarta: Kominfo.

Wardhani, D. (2008). Media Relations Sarana Membangun Reputasi Organisasi. Yogyakarta: Graha Ilmu.

Wardoyo, P. (2019a). Dinilai Berjasa Untuk Jateng, Bupati Karanganyar Raih Anugerah dari PWI Jateng. Retrieved from https://joglosemarnews.com/2019/03/dinilaiberjasa-untuk-jateng-bupati-karanganyar-raih-anugerah-dari-pwi-jateng/

Wardoyo, P. (2019b). Program Jamkesda Resmi Dicabut, Pemkab Karanganyar Dituding Tak Lagi Pro Warga Miskin. Retrieved from https://joglosemarnews.com/2019/01/program-jamkesda-resmi-dicabutpemkab-karanganyar-dituding-tak-lagi-pro-warga-miskin/ 
Zaqiyah, M. (2017). Strategi Humas Kabupaten Karanganyar dalam Upaya Pengembalian Citra Positif (Studi Kasus pada Kasus GLA dan BKK Di Kabupaten Karanganyar). IAIN Surakarta. Retrieved from http:/ / eprints.iain-surakarta.ac.id/449/

Ziana, N. (2018). Metode Komunikasi PDAM Tirta Daroy dalam Penyelesain Komplain Warga Kota Banda Aceh. Universitas Islam Negeri Ar-Raniry Banda Aceh. 